Pengaruh Metode Everyone is A Teacher Here terhadap Motivasi dan Hasil Belajar Siswa Kelas X SMA Negeri I8 Makassar pada Materi Pokok Ikatan Kimia

\title{
Pengaruh Metode Everyone is A Teacher Here terhadap Motivasi dan Hasil Belajar Siswa Kelas X SMA Negeri 18 Makassar pada Materi Pokok Ikatan Kimia
}

\section{The Effect of Everyone is A Teacher Here Method towards Motivation and Student's Achievement $10^{\text {th }}$ Class of SMA Negeri 18 Makassar in The Subject Matter Chemical Bonding}

\author{
1) Resky Amalia Jafar, ${ }^{2}$ Sumiati Side, ${ }^{3)}$ Maryono \\ ${ }^{123)}$ Jurusan Kimia Fakultas Matematika dan Ilmu Pengetahuan Alam \\ Universitas Negeri Makassar, Jl. Dg Tata Raya Makassar, Makassar 90224 \\ Email: reskyamalia37@yahoo.com
}

\begin{abstract}
ABSTRAK
Penelitian ini adalah penelitian eksperimen semu yang bertujuan untuk mengetahui pengaruh metode everyone is a teacher here terhadap motivasi dan hasil belajar siswa kelas X SMA Negeri 18 Makassar pada materi pokok ikatan kimia. Variabel bebas dalam penelitian ini adalah pembelajaran dengan menggunakan metode everyone is a teacher here pada model pembelajaran direct instruction dan pembelajaran tanpa menggunakan metode everyone is a teacher here pada model pembelajaran direct instruction, variabel terikatnya adalah motivasi dan hasil belajar siswa pada materi pokok ikatan kimia. Populasi penelitian ini adalah siswa kelas $\mathrm{X}_{1}-\mathrm{X}_{9}$ SMA Negeri 18 Makassar. Sampel penelitian terdiri atas 2 kelas yaitu kelas $\mathrm{X}_{5}$ sebagai kelas eksperimen yang terdiri dari 28 siswa dan kelas $\mathrm{X}_{7}$ sebagai kelas kontrol yang terdiri dari 28 siswa. Teknik pengumpulan data diperoleh dari tes hasil belajar siswa yang terdiri atas 20 butir soal pilihan ganda yang telah divalidasi dan angket motivasi yang terdiri dari 25 butir pernyataan dengan 4 pilihan jawaban. Teknik analisis data menggunakan analisis statistik deskriptif dan inferensial. Pengujian hipotesis yang dilakukan dengan uji $t$ menghasilkan $\mathrm{t}_{\text {hitung }}>\mathrm{t}_{\text {tabel }}=5,98>2,00$ pada $\alpha=0,05$ untuk motivasi belajar siswa dan $t_{\text {hitung }}>\mathrm{t}_{\text {tabel }}=2,28>2,00$ pada $\alpha=0,05$ untuk hasil belajar siswa, sehingga dapat disimpulkan bahwa ada pengaruh metode everyone is a teacher here terhadap motivasi dan hasil belajar siswa kelas X SMA Negeri 18 Makassar pada materi pokok ikatan kimia. Pengujian hipotesis korelasi menggunakan perhitungan korelasi product moment menghasilkan $r_{\text {hitung }}>r_{\text {tabel }}=0,573>0,374$ pada $\alpha=0.05$. Dengan demikian dapat disimpulkan bahwa terdapat korelasi antara motivasi dan hasil belajar siswa kelas X SMA Negeri 18 Makassar pada materi pokok ikatan kimia. Koefisien korelasi antara motivasi dan hasil belajar siswa pada kelas eksperimen adalah 0,573 yang termasuk dalam kategori "sedang" dan koefisien korelasi antara motivasi dan hasil belajar siswa pada kelas kontrol adalah 0,611 yang termasuk dalam kategori "kuat".

Kata kunci: Everyone is a teacher here, motivasi, hasil belajar siswa, ikatan kimia
\end{abstract}


Pengaruh Metode Everyone is A Teacher Here terhadap Motivasi dan Hasil Belajar

Siswa Kelas X SMA Negeri I8 Makassar pada Materi Pokok Ikatan Kimia

\section{ABSTRACT}

The research was a quasi-experimental that aimed to know the effect of everyone is a teacher here method towards motivation and student achievement in $10^{\text {th }}$ Class of SMA Negeri 18 Makassar in the subject matter of chemical bonding. The independent variable in this research was using everyone is a teacher here on learning direct instruction models and without everyone is a teacher here on learning direct instruction model, the dependent variable was learning motivation and learning achievement on subject matter chemical bond. The population was class $\mathrm{X}_{1}-\mathrm{X}_{9}$ SMA Negeri 18 Makassar. The sample of this research consisted of two classes, namely class $X_{5}$ as a experiment class with the number of students was 28 and class $\mathrm{X}_{7}$ as a control class with the number of students 28 peoples. Data collection techniques derived from students' achievement test consisting of 20 multiple choice items that have been validated and motivation questionnaire consisting of 25 items with four answer choices. Data were analyzed using descriptive and inferential statistical analysis. The hypothesis test using t test shows that $\mathrm{t}_{\text {calculate }}>\mathrm{t}_{\text {table }}=5.98>2.00$ on $\alpha=0.05$ for learning motivation and $\mathrm{t}_{\text {calculate }}>\mathrm{t}_{\text {table }}=2.28>2.00$ on $\alpha=0.05$ for learning achievement, so concluded that there was an effect on the everyone is a teacher here method towards motivation and student achievement in $10^{\text {th }}$ Class of SMA Negeri 18 Makassar in the subject matter of chemical bonding. The correlation hypothesis test using correlation product moment shows that $r_{\text {hitung }}>r_{\text {tabel }}=0.573>0.374$ on $\alpha=0.05$. Concluded that there was correlation between motivation and student achievement in $10^{\text {th }}$ Class of SMA Negeri 18 Makassar in the subject matter of chemical bonding. Coefficient of correlation between motivation and student achievement in experiment class is 0.573 , which is included in the "medium" category and coefficient of correlation between motivation and student achievement in control class is 0.611 , which is included in the "strong" category.

Keywords: Everyone is a teacher here, motivation, student's achievement, chemical bonding

\section{PENDAHULUAN}

Kurikulum merupakan ciri
utama atau syarat mutlak bagi
pendidikan formal. Kurikulum adalah
suatu rencana yang memberi pedoman
dalam proses kegiatan belajar
mengajar. Di dalam sebuah kurikulum
terdapat beberapa komponen-
komponen yaitu tujuan, bahan ajar,
model pembelajaran, metode dan media
pembelajaran serta penilaian.

Model pembelajaran adalah kerangka konseptual yang melukiskan prosedur sistematis dalam mengorganisasikan pengalaman belajar untuk mencapai tujuan belajar tertentu dan berfungsi sebagai pedoman bagi para pengajar dalam merencanakan dan melaksanakan pembelajaran. Setiap model pembelajaran memiliki karakteristik tersendiri yang membedakannya dari model 
Pengaruh Metode Everyone is A Teacher Here terhadap Motivasi dan Hasil Belajar

Siswa Kelas X SMA Negeri 18 Makassar pada Materi Pokok Ikatan Kimia

pembelajaran yang lain. Salah satu model pembelajaran yang umum digunakan dalam pembelajaran adalah model pembelajaran direct instruction.

Model pembelajaran direct instruction merupakan salah satu model pengajaran yang dirancang khusus untuk mengembangkan belajar siswa tentang pengetahuan prosedural dan pengetahuan deklaratif yang terstruktur dengan baik dan dapat dipelajari selangkah demi selangkah. Pengetahuan deklaratif (dapat diungkapkan dengan kata-kata) adalah pengetahuan tentang sesuatu. sedangkan pengetahuan prosedural adalah pengetahuan tentang bagaimana melakukan sesuatu (Amri \& Iif, 2010).

Salah satu pokok bahasan mata pelajaran kimia yang diajarkan di SMA (Sekolah Menengah Atas) adalah ikatan kimia. Dalam materi ini terdapat konsep-konsep yang bersifat abstrak seperti struktur dan bentuk suatu senyawa. Selain konsep yang bersifat abstrak, untuk memahami materi ini siswa harus menguasai dengan baik konsep-konsep yang berkaitan dengan konsep-konsep sebelumnya, seperti struktur atom dan sistem periodik unsur.

Berdasarkan observasi yang dilakukan di kelas X SMA Negeri 18 Makassar, guru menerapkan model direct instruction pada pembelajaran kimia. Ada beberapa siswa yang terlihat bosan dalam menerima materi, kurang semangat dalam belajar, kurangnya keaktifan siswa dalam proses pembelajaran yang ditunjukkan dengan kurangnya pertanyaan maupun tanggapan yang ditujukan untuk guru. Bila siswa diberi latihan soal yang agak sulit, siswa tidak mengerjakan soal dan tidak termotivasi untuk mencari penyelesaian dari soal, mereka lebih senang untuk menunggu guru menyelesaikan soal. Kondisi tersebut menunjukkan bahwa siswa kurang mempunyai motivasi dalam pembelajaran. Kurangnya motivasi belajar siswa dapat mempengaruhi hasil belajar siswa. Berdasarkan hasil wawancara dengan guru kimia kelas $\mathrm{X}$ SMA Negeri 18 Makassar, menyatakan bahwa nilai rata-rata ketuntasan kelas $\mathrm{X}$ terhadap materi ikatan kimia masih rendah yaitu $<30 \%$ dari KKM yang ditetapkan yaitu 75 .

Motivasi belajar merupakan faktor psikis yang bersifat non intelektual. Motivasi berperan khas dalam hal penumbuhan gairah, merasa senang dan semangat untuk belajar. Seseorang yang memiliki motivasi kuat akan mempunyai banyak energi untuk belajar, menggali pengetahuan untuk belajar. Motivasi belajar siswa berkaitan dengan berbagai faktor, seperti materi belajar, bakat siswa, kemenarikan penyajian materi pembelajaran oleh guru, suasana belajar, faktor teman sebaya, dan faktor orang tua (Sardiman, 2010).

Berdasarkan kondisi kelas tersebut, maka perlu ada upaya bagaimana cara menyampaikan pelajaran kimia khususnya materi ikatan kimia yang tepat sehingga dapat menumbuhkan motivasi belajar siswa dan dapat mempengaruhi hasil belajar siswa. Salah satu caranya dengan menggunakan metode pada model pembelajaran direct instruction yang dapat menumbuhkan motivasi belajar siswa. Pemilihan metode pembelajaran 
yang tepat dapat menghantarkan pada tujuan dari pembelajaran yang diharapkan dan dapat pula meningkatkan hasil belajar siswa.

Metode everyone is a teacher here diperkenalkan oleh Melvin L. Silberman. Metode tersebut merupakan salah satu metode yang dapat menumbuhkan motivasi belajar siswa. Metode everyone is a teacher here merupakan metode yang mudah untuk mendapatkan partisipasi seluruh siswa di kelas dan pertanggungjawaban individu. Metode ini memberi kesempatan kepada siswa untuk berperan sebagai guru bagi kawankarannya dan membuat siswa yang selama ini tidak mau terlibat akan ikut serta dalam pembelajaran sehingga terbentuk aktivitas belajar yang partisipatif dan aktif.

Metode everyone is a teacher here membantu siswa untuk mengembangkan kemampuan dalam berpikirnya. Siswa tidak hanya mendengarkan penjelasan guru tetapi siswa melihat, mendengar, bertanya dengan guru atau teman, berdiskusi dengan teman, melakukan dan mengajarkan kepada siswa lainnya sehingga mereka menguasai materi pembelajaran.

Metode everyone is a teacher here pada model pembelajaran direct instruction yang digunakan pada materi pokok Ikatan Kimia diharapkan dapat memotivasi siswa dan dapat menghilangkan kejenuhan dalam belajar kearah pembelajaran yang menciptakan interaktif sesama siswa, sehingga siswa termotivasi untuk belajar kimia yang pada akhirnya dapat memperoleh hasil belajar yang lebih baik. Berdasarkan uraian di atas, maka peneliti mengangkat judul penelitian yaitu pengaruh metode everyone is a teacher here terhadap motivasi dan hasil belajar siswa kelas X SMA Negeri 18 Makassar pada materi pokok ikatan kimia.

\section{METODE PENELITIAN}

Penelitian ini merupakan penelitian eksperimen semu. Variabel dalam penelitian ini terdiri dari variabel bebas yaitu pembelajaran dengan menggunakan metode everyone is a teacher here pada model pembelajaran direct instruction dan pembelajaran tanpa menggunakan metode everyone is $a$ teacher here pada model pembelajaran direct instruction serta variabel terikat yaitu motivasi dan hasil belajar siswa kelas X SMA Negeri 18 Makassar.

Desain penelitian yang digunakan adalah Posttest-Only Control Group Design (Sugiyono, 2013). Dalam desain ini terdapat dua kelas yang dipilih secara random yaitu kelas eksperimen dan kelas kontrol. Kelas eksperimen diajar dengan menggunakan metode pembelajaran everyone is a teacher here sedangkan kelas kontrol diajar tanpa menggunakan metode everyone is a teacher here.

Sampel dalam penelitian ini terdiri dari dua kelas yaitu kelas eksperimen dan kelas kontrol. Kedua kelas dipilih secara random sampling yaitu pengambilan sampel dari populasi secara acak tanpa memperhatikan strata yang ada dalam populasi. Sampel yang terpilih dari penelitian ini yaitu X.5 sebagai kelas eksperimen yang terdiri 
Pengaruh Metode Everyone is A Teacher Here terhadap Motivasi dan Hasil Belajar

Siswa Kelas X SMA Negeri 18 Makassar pada Materi Pokok Ikatan Kimia

dari 28 siswa dan X.7 sebagai kelas kontrol yang terdiri dari 28 siswa.

Instrumen motivasi belajar siswa diperoleh dengan memberikan lembar kuesioner/angket motivasi belajar siswa di akhir pembelajaran materi ikatan kimia. Bentuk alat ukur motivasi belajar siswa ini terdiri dari 25 butir pernyataan dengan menggunakan 4 kriteria jawaban yaitu sangat setuju (SS), setuju (S), tidak setuju (TS), sangat tidak setuju (STS). Cara pemberian bobot pernyataan pada Tabel 1.

Tabel 1. Bobot Pernyataan Angket Motivasi Belajar

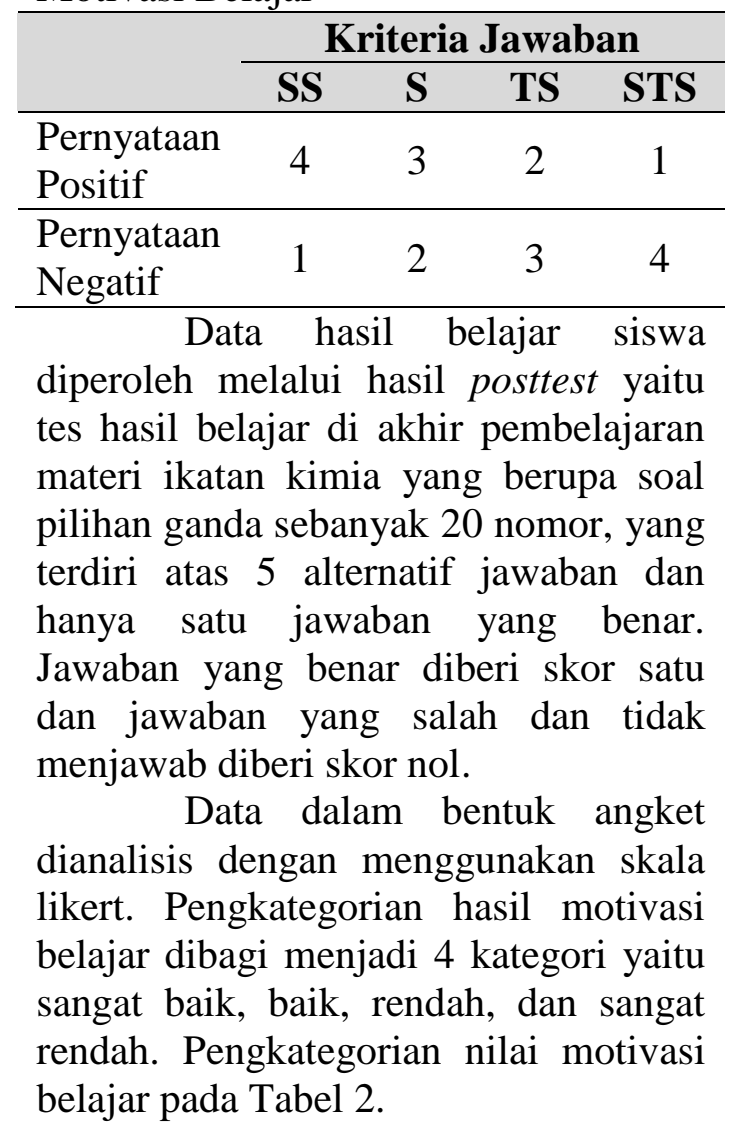

Tabel 2. Kategori Motivasi Belajar Siswa

\begin{tabular}{cc}
\hline Nilai & Kategori \\
\hline $82-100$ & Sangat baik \\
\hline $63-81$ & Baik \\
\hline $44-62$ & Rendah \\
\hline $25-43$ & Sangat rendah \\
\hline \multicolumn{2}{c}{ (Sumber : Hadi. 1986) } \\
hasil posttest diubah
\end{tabular}

kenilai dengan menggunakan rumus:

$$
\text { Nilai }=\frac{\text { skor yang diperoleh Siswa }}{\text { skor maksimum }} \times 100
$$

Data yang diperoleh selanjutnya dikategorikan dalam kategori tuntas dan tidak tuntas. Kriteria Ketuntasan Minimal (KKM) yang digunakan untuk mata pelajaran kimia di SMA Negeri 18 Makassar dapat dilihat pada Tabel 3 .

Tabel 3. Kriteria Ketuntasan Minimal (KKM) di SMA Negeri 18 Makassar

\begin{tabular}{cc}
\hline $\begin{array}{c}\text { Tingkat } \\
\text { Penguasaan }\end{array}$ & Kriteria \\
\hline$<75$ & Tidak tuntas \\
\hline$\geq 75$ & Tuntas \\
\hline (Sumber : SMAN 18 Makassar $)$
\end{tabular}

Analisis statistik inferensial digunakan untuk menguji hipotesis. Sebelum menguji hipotesis, terlebih dahulu dilakukan uji prasyarat berupa uji normalitas dan uji homogenitas. Pengujian normalitas yang digunakan menggunakan rumus kai kuadrat (chi square) dengan $\alpha=0.05$. Rumusnya adalah sebagai berikut:

$$
x_{\text {hitung }}^{2}=\Sigma \frac{(\mathrm{Oi}-\mathrm{Ei})^{2}}{\mathrm{Ei}}
$$


Pengujian homogenitas dengan $\alpha=$ 0.05 menggunakan rumus sebagai berikut:

$$
F_{\text {hitung }}=\frac{\text { Varians besar }}{\text { Varians kecil }}
$$

Pengujian yang digunakan untuk menguji hipotesis adalah uji-t satu pihak dengan $\alpha=0.05$ dan korelasi product moment.

\section{HASIL DAN PEMBAHASAN}

\section{A. Hasil Penelitian}

1. Motivasi belajar

Nilai angket motivasi belajar siswa SMA Negeri 18 Makassar pada kelas eksperimen dan kelas kontrol berdasarkan hasil analisis statistik deskriptif dapat dilihat pada Tabel 4.

Tabel 4. Statistik Deskriptif Motivasi Belajar Siswa pada Kelas Eksperimen dan Kelas Kontrol

\begin{tabular}{lcc}
\hline \multirow{2}{*}{ Statistik } & \multicolumn{2}{c}{ Nilai Statistik } \\
\cline { 2 - 3 } & $\begin{array}{c}\text { Kelas } \\
\text { Ekpserimen }\end{array}$ & $\begin{array}{c}\text { Kelas } \\
\text { Kontrol }\end{array}$ \\
\hline $\begin{array}{l}\text { Jumlah } \\
\text { Siswa }\end{array}$ & 28 & 28 \\
\hline $\begin{array}{l}\text { Nilai } \\
\text { Tertinggi }\end{array}$ & 87 & 85 \\
\hline $\begin{array}{l}\text { Nilai } \\
\text { Terendah }\end{array}$ & 71 & 63 \\
\hline $\begin{array}{l}\text { Nilai Rata- } \\
\text { rata }\end{array}$ & 80.36 & 71.50 \\
\hline $\begin{array}{l}\text { Standar } \\
\text { Deviasi }\end{array}$ & 4.64 & 6.31 \\
\hline
\end{tabular}

Berdasarkan angket yang diberikan kepada siswa, dapat dilihat frekuensi kategori angket motivasi pada Tabel 6 .

\section{Hasil Belajar Siswa}

Nilai hasil belajar siswa SMA Negeri 18 Makassar pada kelas eksperimen dan kelas kontrol berdasarkan hasil analisis statistik deskriptif dapat dilihat pada Tabel 5.

Tabel 5. Statistik Deskriptif Hasil Belajar Siswa pada Kelas Eksperimen dan Kelas Kontrol

\begin{tabular}{lcc}
\hline \multirow{2}{*}{ Statistik } & \multicolumn{2}{c}{ Nilai Statistik } \\
\cline { 2 - 3 } & $\begin{array}{c}\text { Kelas } \\
\text { Ekserimen }\end{array}$ & $\begin{array}{c}\text { Kelas } \\
\text { Kontrol }\end{array}$ \\
\hline $\begin{array}{l}\text { Jumlah } \\
\text { Siswa }\end{array}$ & 28 & 28 \\
\hline $\begin{array}{l}\text { Nilai } \\
\text { Tertinggi }\end{array}$ & 90 & 85 \\
\hline $\begin{array}{l}\text { Nilai } \\
\text { Terendah }\end{array}$ & 45 & 45 \\
\hline $\begin{array}{l}\text { Nilai Rata- } \\
\text { rata }\end{array}$ & 76.5 & 70.0 \\
\hline $\begin{array}{l}\text { Standar } \\
\text { Deviasi }\end{array}$ & 10.6 & 10.7 \\
\hline
\end{tabular}

Hasil belajar siswa dapat dikelompokkan berdasarkan kriteria nilai ketuntasan hasil belajar siswa di SMA Negeri 18 Makassar pada Tabel 7. 
Tabel 6. Frekuensi Kategori Angket Motivasi

\begin{tabular}{lcccc}
\hline \multirow{2}{*}{ Kategori } & \multicolumn{2}{c}{ Eksperimen } & \multicolumn{2}{c}{ Kontrol } \\
\cline { 2 - 5 } & Frekuensi & Persentase & Frekuensi & Persentase \\
\hline Sangat Baik & 24 & $85.71 \%$ & 6 & $21.43 \%$ \\
\hline Baik & 4 & $14.29 \%$ & 22 & $78.57 \%$ \\
\hline Rendah & 0 & $0 \%$ & 0 & $0 \%$ \\
\hline Sangat Rendah & 0 & $0 \%$ & 0 & $0 \%$ \\
\hline
\end{tabular}

Tabel 7. Kriteria Ketuntasan Hasil Belajar Siswa

\begin{tabular}{clcccc}
\hline \multirow{2}{*}{ Nilai } & Kriteria & \multicolumn{2}{c}{ Eksperimen } & \multicolumn{2}{c}{ Kontrol } \\
\cline { 3 - 6 } & Ketuntasan & Frekuensi & Persentase & Frekuensi & Persentase \\
\hline$\geq 75$ & Tuntas & 20 & $71.42 \%$ & 12 & $42.86 \%$ \\
$<75$ & Tidak tuntas & 8 & $28.58 \%$ & 16 & $57.14 \%$ \\
\hline
\end{tabular}

\section{B. PEMBAHASAN}

Siswa SMAN 18 Makassar memiliki motivasi yang beragam. Hal tersebut terlihat dari hasil pengelompokkan tingkat motivasi yang dimiliki siswa ke dalam empat kategori. Hasil perhitungan angket motivasi siswa, diperoleh bahwa skor rata-rata motivasi siswa dari setiap pernyataan positif dan negatif pada kelas eksperimen yang menggunakan metode everyone is a teacher here pada model pembelajaran direct instruction yaitu 80.36 lebih tinggi daripada skor ratarata motivasi siswa pada kelas kontrol yang hanya menggunakan model pembelajaran direct instruction yaitu 71.50 (Tabel 4). Frekuensi motivasi belajar siswa pada kelas eksperimen yang termasuk dalam kategori sangat baik sebanyak 24 siswa sedangkan pada kelas kontrol sebanyak 6 siswa (Tabel 5). Hal ini menunjukkan bahwa motivasi belajar siswa pada kelas kontrol lebih rendah dibandingkan dengan kelas eksperimen.
Kurangnya motivasi siswa pada kelas kontrol disebabkan karena pada proses pembelajaran didalam kelas hanya siswa yang rajin dan memiliki pengetahuan lebih yang antusias sedangkan siswa yang lain merasa "ogah-ogahan" mengikuti pembelajaran. Sedangkan pada kelas eksperimen dalam proses pembelajaran sebagian besar siswa sangat antusias. Hal tersebut didukung oleh hasil analisis aktivitas siswa pada kelas eksperimen sebesar 60\% siswa yang sering bertanya dan memberi pendapat sedangkan pada kelas kontrol, 33,33\% siswa yang sering bertanya dan memberi pendapat.

Pada kelas eksperimen diterapkan metode everyone is a teacher here yang dilakukan dengan kompetisi antar individu, pemberian pujian dan hadiah dapat meningkatkan motivasi belajar siswa. Kompetisi, pujian, dan pemberian hadiah merupakan sebagian cara untuk meningkatkan motivasi belajar. Kompetisi dapat meningkatkan 
motivasi belajar siswa karena adanya persaingan anatar individu atau kelompok akan membuat siswa semakin bersemangat agar mendapatkan hasil terbaik.

Dalam penerapan metode everyone is a teacher here, guru memberikan pujian kepada siswa yang berhasil menjawab pertanyaan dengan benar. Pujian dapat menjadi salah satu cara yang dapat memotivasi belajar siswa. Pemberian pujian yang tepat kepada siswa dapat membuat siswa merasa bangga, sehingga siswa akan lebih bersemangat dalam belajar agar mendapatkan hasil yang lebih baik. Pujian tersebut berupa kata-kata seperti jawaban yang sangan tepat, pintar sekali dan sebagainya. Demikian juga dengan pemberian hadiah, dapat membuat siswa lebih bersemangat dalam belajar karena merasa hasil kerja kerasnya mendapatkan penghargaan.

Tinggi rendahnya motivasi siswa juga mempengaruhi hasil belajar siswa. Motivasi belajar merupakan suatu tenaga yang mendorong siswa agar selalu semangat dan memiliki energi serta kekuatan dalam melakukan aktivitas belajar, sehingga mencapai tujuan yang diharapkan. Siswa yang memiliki motivasi belajar yang tinggi akan membuat hasil belajarnya tinggi. Hal ini dibuktikan dengan hasil korelasi antara motivasi dan hasil belajar. Koefisien korelasi pada kelas ekperimen sebesar 0,573 yang termasuk dalam kategori "sedang" dengan koefisien determinasi sebesar 32,83\% yang menandakan bahwa motivasi belajar berkontribusi terhadap hasil belajar siswa sebesar 32,83\%. Pada kelas kontrol, diperoleh koefisien korelasi sebesar 0,611 yang termasuk dalam kategori 'kuat" dengan koefisien determinasi sebesar $37,33 \%$ yang menandakan bahwa motivasi belajar berkontribusi terhadap hasil belajar siswa sebesar $37,33 \%$. Nilai positif hasil koefisien korelasi menunjukkan hubungan searah yang berarti motivasi belajar naik maka hasil belajar juga naik.

Adanya perbedaan koefisien korelasi motivasi belajar dan hasil belajar siswa pada kelas eksperimen dan kelas kontrol disebabkan karena pada saat pengisian angket motivasi siswa, terdapat siswa yang asal-asalan dan terburu-buru mengisi angket tersebut. Hal tersebut disebabkan karena pada saat pengisian angket motivasi belajar di kelas kontrol, waktu telah menunjukkan jam istirahat sehingga ada siswa yang cepat-cepat mengisi angket tersebut tanpa membaca pernyataan angket dengan baik.

Hal tersebut juga disebabkan karena terdapat siswa yang memiliki motivasi yang tinggi tetapi hasil belajarnya rendah karena pada saat tes hasil belajar, kondisi fisik siswa tersebut kurang sehat atau pikirannya terganggu karena ada masalah sehingga mempengaruhi hasil belajarnya. Kontribusi motivasi belajar terhadap hasil belajar siswa tidak mencapai $100 \%$ disebabkan karena motivasi belajar bukan salah satunya faktor yang mempengaruhi hasil belajar, juga terdapat faktor kesehatan, faktor lingkungan sekolah, faktor keluarga dan juga faktor kelelahan.

Berdasarkan hasil analisis deskriptif yang dianalisis secara manual, diperoleh bahwa perolehan 
Pengaruh Metode Everyone is A Teacher Here terhadap Motivasi dan Hasil Belajar

Siswa Kelas X SMA Negeri 18 Makassar pada Materi Pokok Ikatan Kimia

hasil belajar kelas eksperimen lebih besar dibandingkan dengan kelas kontrol. Pada perolehan hasil belajar posttest, terlihat adanya perbedaan nilai rata-rata yang cukup besar, dimana nilai rata-rata kelas eksperimen adalah 76.5 dan nilai rata-rata kelas kontrol adalah 70 (Tabel 6).

Perbedaan hasil belajar antara kelas eksperimen dan kelas kontrol pada materi ikatan kimia menurut pengamatan peneliti disebabkan oleh minat dan motivasi belajar siswa di kelas saat mengikuti pembelajaran. Di kelas eksperimen, yaitu kelas yang diajar dengan menggunakan metode everyone is a teacher here, siswa terlihat lebih tertarik dan termotivasi untuk belajar karena metode ini memberikan kesempatan pada setiap siswa untuk bertindak sebagai seorang pengajar terhadap siswa lain. Mengajar teman sebaya ini memberikan kesempatan kepada siswa untuk mempelajari sesuatu dengan baik pada waktu yang sama, saat siswa menjadi narasumber bagi yang lain. Siswa mampu mencari dan menemukan sendiri konsep-konsep pada materi ikatan kimia. Melalui metode ini juga siswa dapat menambah kepercayaan kemampuan berfikir sendiri, mengembangkan keberanian dan keterampilannya dalam menjawab dan mengemukakan pendapat.

Pembelajaran kimia yang hanya menggunakan model direct instruction, selama proses pembelajaran terlihat kurangnya aktivitas siswa. Siswa cenderung pasif karena interaksi hanya berlangsung satu arah dan proses pembelajaran hanya terjadi aktivitas pemberian informasi yang harus "ditelan" oleh siswa, yang wajib diingat dan dihafal. Pembelajaran ini menyebabkan siswa menjadi bosan dan bercanda dalam kelas. Sehingga siswa tidak mendengarkan penjelasan dari guru dan cepat lupa tentang materi pembelajaran yang baru saja dipelajari.

Hasil lembar observasi aktivitas pembelajaran dengan menggunakan metode everyone is a teacher here pada model pembelajaran direct instruction diperoleh bahwa siswa yang diajar dengan menggunakan metode everyone is a teacher here lebih aktif dan antusias dalam kegiatan pembelajaran. Hal tersebut dilihat dari persentase aktivitas belajar siswa pada kelas ekperimen lebih besar dibandingkan pada kelas kontrol. Pada kelas eksperimen, siswa yang membawa buku atau literatur pada saat pembelajaran sebesar $66.67 \%$ sedangkan pada kelas kontrol sebesar 53\%. Siswa yang mendengarkan dengan aktif penjelasan guru pada kelas eksperimen sebesar $80 \%$ sedangkan pada kelas kontrol sebesar $60 \%$. Siswa yang menyelesaikan latihan soal pada kelas eksperimen sebesar 100\% sedangkan pada kelas kontrol sebesar 93\%. Pada kelas eksperimen, siswa yang aktif membaca buku untuk mencari sumber jawaban yang benar dalam mengerjakan latihan soal sebesar $86.67 \%$ sedangkan pada kelas kontrol sebesar $73 \%$. Siswa yang sering bertanya dan memberi pendapat pada kelas eksperimen sebesar $60 \%$ sedangkan pada kelas kontrol hanya sebesar $33.33 \%$.

Persentase ketuntasan yang diperoleh dengan menggunakan model pembelajaran direct instruction pada 
kelas kontrol adalah $42.86 \%$ sedangkan dengan menggunakan metode everyone is a teaher here pada kelas eksperimen diperoleh pesentase ketuntasan sebesar $71.42 \%$ (Tabel 7). Hal ini disebabkan karena metode pembelajaran everyone is a teacher here efektif untuk mendorong keikutsertaan siswa sejak awal dalam proses pembelajaran dan juga dapat meningkatkan motivasi siswa dalam proses pembelajaran. Ketika siswa aktif dalam proses pembelajaran, berarti siswa yang mendominasi aktifitas pembelajaran. Dengan ini siswa secara aktif menggunakan otak, baik untuk menemukan ide pokok dari materi pelajaran ataupun memecahkan persoalan.

\section{KESIMPULANDAN SARAN}

\section{A. Kesimpulan}

Berdasarkan hasil analisis data penelitian dan pembahasan dapat disimpulkan bahwa penggunaan metode everyone is a teacher here pada model pembelajaran direct instruction berpengaruh terhadap motivasi dan hasil belajar siswa, serta ada hubungan (korelasi) antara motivasi dan hasil belajar siswa kelas X SMA Negeri 18 Makassar pada materi pokok ikatan kimia.

\section{B. Saran}

Berdasarkan pengalaman peneliti dalam melaksanakan penelitian, maka saran yang diberikan yakni kepada para guru atau tenaga pengajar khususnya guru kimia untuk mempertimbangkan penerapan metode pembelajaran everyone is a teacher here sebagai upaya meningkatkan motivasi belajar siswa dan hasil belajar siswa dengan memadukan beberapa model pembelajaran.

\section{DAFTAR PUSTAKA}

Amri \& Iif Khoiru Ahmadi. 2010. Konstruksi Pengembangan Pembelajaran (Pengaruhnya Terhadap Mekanisme dan Praktik Kurikulum). Jakarta: PT Prestasi Pustakarya.

Hadi, Sutrisno. 1986. Metodologi Penelitian. Yogyakarta: Fakultas Psikologi UGM.

Sardiman, A. M. 2010. Interaksi dan Motivasi Belajar Mengajar. Jakarta: PT Raja Grafindo Persada.

Sugiyono. 2013. Metode Penelitian Pendidikan. Bandung: Alfabeta. 